\title{
The influence of browsing motivation toward consumer impulse buying behavior on Indonesian M-commerce
}

\author{
Mufadhzil \& Y. Alversia \\ Master of Management, Universitas Indonesia, Indonesia
}

\begin{abstract}
The purpose of this study is to examine how browsing motivation influences consumers' urge to buy impulsively (UBI) during the COVID-19 pandemic. Based on the stimulusorganism-response (S-O-R) framework and motivation theory, this study investigated situation factor interpersonal influence (UBI), visual appeal (VA), portability (PB), and reaction factor in $\mathrm{m}$-commerce to examine online impulsive buying. This study also investigated the impulse buying tendency personality trait as a moderating factor that affects the relationship between browsing motivation and urge to buy impulsively. We collected data from 368 respondents via an online questionnaire and carried out analysis using SEM-AMOS. The result indicates that situation factors affect browsing motivation differently. While utilitarian browsing (UB) has a significant and negative influence on consumers' urge to buy impulsively, hedonic browsing (HB) has a significant and positive influence on consumers' urge to buy impulsively. Further, impulsive buying tendency (IBT) significantly moderates the relationship between browsing motivation and consumers' urge to buy impulsively.
\end{abstract}

\section{INTRODUCTION}

At the end of 2019, the world was shocked by the spread of a disease called COVID-19 (coronavirus disease 2019). To stop a wider spread, the Indonesia government had imposed PSBB (large-scale social restrictions). During PSBB, there was a change in people's shopping behavior from offline to online by $14 \%$ (Kantar, 2020). The shift in patterns from offline to online also affects consumer shopping behavior, one of which is impulsive buying behavior (Verhagen and van Dolen, 2011).

According to X. Zheng et al. (2019), situation cues such as the visual appearance of m-commerce applications, interpersonal influence, and portability are considered to influence impulsive purchases from consumers. Meanwhile, the impulsive buying tendency (IBT) is also found to be an influencing factor toward impulsive purchase behavior (Chen \& Yao., 2018).

This study expands the motivation theory and adopts hedonic browsing and utilitarian browsing as two motivation values to investigate the consumer's impulse buying behavior. Also, this study suggests that IBT as a personality trait moderates the relationship between browsing motivation and impulsive buying behavior.

The research questions of this study are: (1) Do situation cues affect browsing motivation on mcommerce during the COVID-19 pandemic?; (2) does browsing motivation affect consumers' urge to buy impulsively on m-commerce during the COVID-19 pandemic?; and (3) does the moderating role played by IBT affect the relationship between browsing motivation toward the urge to buy impulsively during the COVID-19 pandemic?

\section{LITERATURE REVIEW}

Based on previous literature reviews, family and friends are considered to be able to direct consumer purchasing behavior patterns in collectivist countries (Lee and Kacen, 2008). The research 
conducted by X. Zheng et al. (2019) shows that the interpersonal influence positively affects hedonic browsing behavior. Meanwhile, consumers with utilitarian values, according to Ismagilova et al. (2019), tend to find information about a product that was previously provided by other consumers before shopping.

Visual appeal is closely related to the appearance of letters and other visual elements (such as graphics) as well as any efforts made to increase the visual appeal of the web as a whole (Parboteeah et al., 2009). Therefore, visual attractiveness is expected to encourage consumers to obtain hedonistic or utilitarian values by browsing $\mathrm{m}$-commerce applications. This statement is supported by research from X. Zheng et al. (2019), which shows that visual appeal positively and significantly influences hedonic browsing or utilitarian browsing.

Portability is a key feature that concerns e-commerce users (Okazaki and Mendez, 2013) because consumers can connect with the m-commerce application anytime and anywhere so that it can increase the length of exposure time. According to the research by X. Zheng et al. (2019), portability positively and significantly influences utilitarian browsing behavior, but it is the opposite for hedonic browsing.

Browsing is a way consumers access information in an online environment, which is the first level in information retrieval and decision making (Rowley, 2002). Utilitarian and hedonic browsing influence impulsive buying (Madhavaram and Leverie, 2004). Research by X. Zheng et al. (2019) showed that utilitarian browsing is negatively associated with impulsive buying, while hedonic browsing has a positive effect.

IBT is a personality trait that refers to the extent to which an individual tends to make unwanted and direct purchases with little consideration or evaluation of the consequences (Flight et al., 2012). Previous research also found that IBT significantly and positively predicts impulsive buying (Liu et al., 2013).

\section{RESEARCH METHODS}

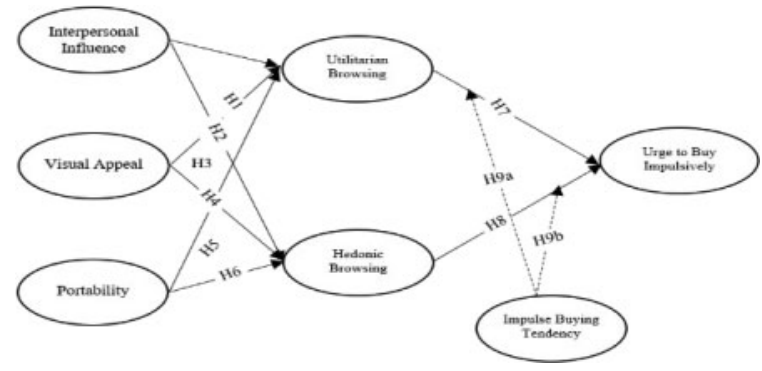

Figure 1. Research model.

We collected data via an online questionnaire to measure customer perception concerning the constructs of interest. Our target sample is consumers who made purchases in October 2020 through one of the m-commerce applications during the COVID-19 pandemic. We invited participants by placing a link on Instagram and WhatsApp, and 368 valid responses were obtained for data analysis.

All of the questionnaire items in this research were adapted from previous studies, with appropriate modification to fit the research context, and assessed on a six-point Likert scale ranging from 1 (strongly disagree) to 6 (strongly agree).

This study selected structural equation modeling (SEM) to evaluate the research models, and hypotheses were proposed. Therefore, we used SPSS 25 and AMOS 23 to conduct the structural equation modeling estimation. 


\section{RESULTS}

We tested the proposed hypotheses with SEM-AMOS. The results show that most of the hypotheses support the relationship between constructs in the research model. The results of hypotheses testing are shown in Table 1.

Table 1. Hypothesis testing results.

\begin{tabular}{llll}
\hline Hypotheses & C.R & P & Result \\
\hline $\begin{array}{l}\text { H1: "Interpersonal influence" positively affects the "utilitarian browsing" } \\
\text { by m-commerce application users during the COVID-19 pandemic }\end{array}$ & 3.674 & $* * *$ & Supported \\
$\begin{array}{l}\text { H2: "Interpersonal influence" positively affects the "hedonic browsing" } \\
\text { by m-commerce application users during the COVID-19 pandemic }\end{array}$ & 5.403 & $* * *$ & Supported \\
$\begin{array}{l}\text { H3: "Visual appeal" positively affects the "utilitarian browsing" by } \\
\text { m-commerce application users during the COVID-19 pandemic }\end{array}$ & 4.836 & $* * *$ & Supported \\
$\begin{array}{l}\text { H4: "Visual appeal" positively affects the "hedonic browsing" by } \\
\text { m-commerce application users during the COVID-19 pandemic }\end{array}$ & 7.713 & $* * *$ & Supported \\
$\begin{array}{l}\text { H5: "Portability" positively affects the "utilitarian browsing" by } \\
\text { m-commerce application users during the COVID-19 pandemic }\end{array}$ & 6.648 & $* * *$ & Supported \\
$\begin{array}{l}\text { H6: "Portability" positively affects the "hedonic browsing" by } \\
\text { m-commerce application users during the COVID-19 pandemic }\end{array}$ & -.400 & .689 & Not Supported \\
$\begin{array}{l}\text { H7: "Hedonic browsing" positively affects the "urge to buy impulsively" } \\
\text { by m-commerce application users during the COVID-19 pandemic }\end{array}$ & -2.929 & .003 & Supported \\
$\begin{array}{l}\text { H8: "Hedonic browsing" negatively affects the "urge to buy impulsively" } \\
\text { by m-commerce application users during the COVID-19 pandemic }\end{array}$ & 10.222 & $* * *$ & Supported \\
\hline
\end{tabular}

Hypothesis nine suggests that IBT moderates the relationship between browsing motivation and urge to buy impulsively. The results show that IBT is a significant predictor of the urge to buy impulsively. The results of hypothesis nine are shown in Table 2.

Table 2. Hypothesis testing results

\begin{tabular}{llll}
\hline Hypotheses & C.R & P & Result \\
\hline $\begin{array}{l}\text { H9a: "IBT" moderates the relationship between "utilitarian browsing" and } \\
\text { the "urge to buy impulsively" during the COVID-19 pandemic. }\end{array}$ & 0.007 & $* * *$ & Supported \\
$\begin{array}{l}\text { H9b: "IBT" moderates the relationship between "hedonic browsing" and the } \\
\text { "urge to buy impulsively" during the COVID-19 pandemic }\end{array}$ & 0.005 & $* * *$ & Supported \\
\hline
\end{tabular}

\section{CONCLUSION}

First, interpersonal influence has a significant impact on both consumer browsing motivations. This result differs from a previous study by X. Zheng et al. (2019), who suggested that interpersonal influence has a significant impact on hedonic browsing but an insignificant impact on the consumer with utilitarian browsing motivation.

Second, the visual appeal has a significant effect on both consumer browsing motivations. The finding is consistent with the previous study by X. Zheng et al. (2019), who suggested that $\mathrm{m}-$ commerce does not only make consumer feel good but also provide information to improving efficiency in the consumer shopping experience in m-commerce.

Third, portability has a significant relationship with utilitarian browsing. However, on hedonic browsing, portability does not have a significant impact. This result is consistent with a previous 
study by X. Zheng et al. (2019), who suggested that consumers with hedonic motivation are just concerned with pleasure and enjoyment of shopping behavior, but for the consumer with utilitarian motivation, portability is about efficiency.

Fourth, utilitarian browsing has a significant and negative effect on the urge to buy impulsively. Meanwhile, hedonic browsing has a significant and positive impact. This finding is similar to the study conducted by Park et al. (2012), who suggested that people with utilitarian motivation are more concerned with the goal in shopping, while people with hedonic motivation are mostly concerned with fun and enjoyment.

Fifth, IBT moderates the relationship between browsing motivation toward the urge to buy impulsively. This finding proposes that a higher personality trait of IBT in both consumer utilitarian and hedonic browsing motivations will increase the intention to buy impulsively.

This study provides information on how situational factors affects consumer behavior toward the urge to buy impulsively on m-commerce, which might help m-commerce providers to plan their marketing strategies. For example, visual appeal and interpersonal influence, which have a significant effect on consumers with utilitarian and hedonic values, are a hint for the m-commerce retailers to design the visual appearance of their m-commerce application and also to provide interesting product information visually to fulfill utilitarian consumers' need.

This study focuses only on m-commerce customers and cross-sectional research because of limited resources and time. Future research could adopt experiment methods or a longitudinal approach to examine consumer buying behavior.

\section{REFERENCES}

Chen, C.C., \& Yao, J.Y., (2018). What drives impulse buying behaviors in a mobile auction? The perspective of the S-O-R model. Telematics and Informatics, 35, 1249-1262.

Flight, R. L., Rountree, M. M., \& Beatty, S. E. (2012). Feeling the urge: Affect in impulsive and compulsive buying. The Journal of Marketing Theory and Practice, 20, 453-466.

Ismagilova, E., Dwivedi, Y. K., \& Slade, E. (2019). Perceived helpfulness of eWOM: Emotions, fairness and rationality. Journal of Retailing and Consumer Services. https://doi.org/10.1016/j.jretconser.2019.02.002.

Lee, J. A., \& Kacen, J. J. (2008). Cultural influences on consumer satisfaction with impulse and planned purchase decisions. Journal of Business Research, 61(3), 265-272.

Madhavaram. S. \& Laverie, D.A. (2004) Exploring Impulse Purchasing on the Internet. Advances in consumer research. Association for Consumer Research (U.S.), 31(1).

Okazaki, S., \& Mendez, F. (2013). Exploring convenience in mobile commerce: Moderating effects of gender. Computers in Human Behavior, 29(3), 1234-1242.

Parboteeah, D. V., Valacich, J. S., \& Wells, J. D. (2009). The influence of website characteristics on a consumer's urge to buy impulsively. Information Systems Research, 20, 60-78.

Park, E. J., Kim, E. Y., Funches, V. M., \& Foxx, W. (2012). Apparel product attributes, web browsing, and e-impulse buying on shopping websites. Journal of Business Research, 65(11), 1583-1589.

Rowley, J. (2002). Window' shopping and browsing opportunities in cyberspace. Journal of Consumer Behaviour, 1(4), 369-378.

Verhagen, T. \& van Dolen, W. (2011). The influence of online store beliefs on consumer online impulse buying: a model and empirical application. Inf. Manage, 48(8), 320-327.

X. Zheng, et al. (2019). Understanding impulse buying in mobile commerce: An investigation into hedonic and utilitarian browsing. International Journal of Information Management, 48 (2019), 151-160. 